\title{
DEFERRING THE OTHER AND APPARITION OF THE INAPPARENT: HAUNTOLOGICAL PHENOMENA IN A. L. KENNEDY'S COLLECTION OF SHORT STORIES INDELIBLE ACTS (2002)
}

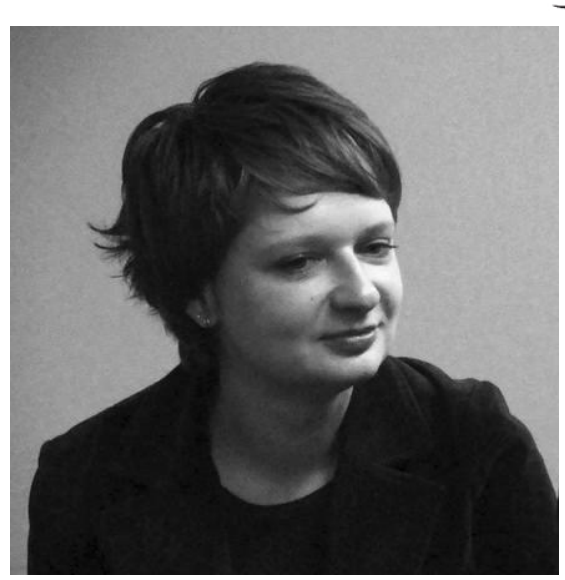

(C) Viktoriia Ivanenko, PhD, Assistant Professor, Assistant Professor of the Department of the V. I. Fesenko Theory and History of World Literature at Kyiv National Linguistic University, Laboratorna Street, 5/17 (building № 3), Kyiv, 03680, Ukraine, svitlit1@gmail.com.

In A. L. Kennedy's collection of short stories Indelible Acts the internal deferring of Self as the Other, the internal differance that leads to the questioning of the "I", which is a secret out there for no one, doesn't differ much from deferring of the Other within one's Self. It is represented through various hauntological forms of apparition of the inapparent such as the engraving of "grapho" marks into human body, into the texture of memory, or into paper. The hauntological meaning of Latin word 'differre' (both in its spacial and temporal meaning) becomes a semantic dominance in the collection, and fictionally represents the internal violence of the "I" in an endlessly deferred present time.

Key words: differance, presence, absence, apparition, deferring, the Other.

"How can another see into me, into my most secret self, without my being able to see in there myself? And without my being able to see him in me. And if my secret self, that which can be revealed only to the other, to the wholly other, to God if you wish, is a secret that I will never reflect on, that I will never know or experience or possess as my own, then what sense is there in saying that it is my secret, or in saying more generally that a secret belongs, that it is proper to or belongs to some one, or to some other who remains someone. It's perhaps there that we find the secret of secrecy. Namely, that it is not a matter of knowing and that it is there for no one. A secret doesn't belong, it can never be said to be at home or in its place. The question of the self: who am I not in the sense of who am I but rather who is this I that can say who? 
What is the I and what becomes of responsibility once the identity of the I trembles in secret?” (Derrida, 2008).

This statement from Derrida's The Gift of Death could be used as a comprehensive synopsis for both A.L. Kennedy's writing in general, and for her collection of short stories Indelible Acts (2002) in particular. The characters of all twelve short stories are the people in "varying existential states of desperation" (Smith, 2002). This desperation is caused by what Derrida calls the desire "to learn to live finally" (Derrida, 2006). French philosopher claims that "to live, by definition, is not something one learns. Not from oneself, it is not learned from life, taught by life. Only from the other and by death.In any case from the other at the edge of life. At the internal border or the external border, it is a heterodidactics between life and death" (Derrida, 2006: XVII). And what lies between self and the other, between one and some other, in this case, can only maintain itself with some ghost, can only talk with or about some ghost [s'entretenir de quelque fantôme]. Derrida insists that ghost or spirit is "neither substance, nor essence, nor existence", it is "never present as such" (Derrida, 2006: XVII). Through the phonetic interplay of "haunt" and "ontologie” in his native French, Derrida coins theory of hauntology, which combines the notion of ontology being haunted by teleology and eschatology: "repetition and the first time, but also repetition and the last time, since the singularity of any first time, makes of it also a last time. Each time it is the event itself, a first time is a last time. Altogether other. Staging for the end of history” (Derrida, 2006:10). Thus, Being becomes a constant and unique history of deferring oneself in the context of individual and collective time ("the time is out of joint"). The Self that questions its Self is always haunted by non-Self, other, the other that is being suppressed deferred, and nonpresent, while this non-presence finds its way to its spectral/ghostly apparitions and marks the Self. This is something that Derrida explains in Difference when he rereads Freudian theory of psychological detour: "The one is only the other deferred, the one differing from the other. The one is the other in differance, the one is the differance from the other. Every apparently rigorous and irreducible opposition... is thus said to be, at one time or another, a "theoretical fiction" (Derrida, 2004: 291). Thus, deferring the other and the apparition of the inapparent is the necessary condition for self-identification. When Self realizes this hauntological presence of the Other within the Self's construction, and takes on the responsibility for Self's differance, then, as Derrida claims, individual and historical justice becomes possible: "no justice...seems possible or thinkable without the principle of some responsibility, beyond all living present, within that which disjoins the living present, before the ghosts of those who are not yet born or who are already dead... Without 
this non-contemporaneity with itself of the living present, without that which secretly unhinges it, without the responsibility and this respect for justice concerning those who are not there, of those who are no longer or who are not yet present and living, what sense would there be to ask the question "where?" "where tomorrow?" “whither?” (Derrida, 2006: XVIII).

Deferring the other in A.L. Kennedy's collection of short stories takes on different forms while it is always about the trauma of inner deferring and about the secrecy of an "I" with the deferred Other, the "I" that longs to belong, but always fails to do so, and is there for no one.

In a short story Indelible Acts from the collectionthe main character/narratorand her lover Laurie in the short nights they spend together away from Laurie's wife try to impress each other with marks (of a sexual type) inscribed in the body and memory, with "indelible acts". Laurie avoids the marks while the narrator longs "for marks, for brands in the memory” (Kennedy, 2002: 115). These marks inscribed in narrator's body and memory carry the function of signification since they stand for and signify the temporal absence of the lover, they substitute for presence as all marks/signs do. The mark, thus, becomes the presence of absence, and the sign of the deferred other: "I'm more used to the short nights when we are trying to impress. They were when I pushed for something to stay with me while he did not, for marks, for brands in the memory, indelible acts" (Kennedy, 2002: 115). The narrator hopes that this deferred significant other would become somebody else as Laurie isn't planning on divorcing his wife, which obviously makes the narrator hurt: "He could have been anybody" (Kennedy, 2002: 113). In her thoughts the narrator fits on Laurie's touches and sexual desires onto someone else, thus trying to re-contextualize the marks engraved in her body and memory (Royle, 2003: 68). This would allow the narrator to also become somebody else in the movement of differing and deferring, to change this hurtful identity of being a part of someone else's husband. The climax of the story coincides with the narrator's understanding that the pain of Laurie's being there exceeds the pain of his absence, and the mark on her body as any kind of "grapho" should outlive its "author": this is the moment when writing on the body coincides with the actual orthographical writing, and the reader learns that the narrator writes letters to Laurie's wife (and never mails them). It becomes apparent that the narrator is actually Laurie's deferred wife, and in order to do justice to her own identity, she should get rid of Laurie and his marks: "But I find, more and more, that I write out what happened, what happens, in letters I never post - letters to a wife a don't know. Although we must have a few things in common, that's what I'd suppose. We must 
both look at him, walking in sunlight, and find him beautiful.”: "But I find, more and more, that I write out what happened, what happens, in letters I never post - letters to a wife a don't know. Although we must have a few things in common, that's what I'd suppose. We must both look at him, walking in sunlight, and find him beautiful” (Kennedy, 2002: 117).

The deferred wife is also a haunting other of the short story Spared. It begins with the sentence: "Things could go wrong with one letter, he knew that now" (Kennedy, 2002: 3). This "now" is the moment (temporalizing) and place (spacing) of differance for the main character Greg, there are two Gregs in the "now": the one who knows how things could go wrong with one letter, and the one who still doesn't. Greg who doesn't know about the letter and its consequences is about to make a move (the indelible act, of course) that would lead to the construction of Greg-who-knows in the future. This simultaneous non-modal, but out-of-joint differential co-existence of the past, present, and future is the basic form of hauntology. Thus, hauntological nature of Indelible Acts becomes apparent right in the first sentence that opens the collection. Differance begins with one letter, with a mark, with a "grapho". And, as Derrida claims, one letter could become "silent, secret, and discreet, like a tomb" (Derrida, 2004: 280). A little pause that Greg takes before “m” and a bit of stress he puts on the letter when he first meets his future mistress in the shop line marks his status: he is married: "He found it so terribly, pleasantly effortless to say, 'Actually, I moved here ten years ago.' There had only been a little thickness about the m, a tiny falter that might have suggested a stammer, or a moment's pause to let him total up those years. Nobody listening, surely, would have guessed his intended sentence had been, 'Actually I'm married In the course of one consonant everything had changed" (Kennedy, 2002: 3). At the moment when "m-mark" comes to the scene of presence Greg embarks on his inner process of differance: he starts deferring his wife within himself. However, the more deferred and inapparent becomes his wife, the more she takes apparitions through Greg's mistress. Greg is trembling with joy to learn his mistress' name because he wants it to be different from his wife's name. Later on, he dreams about oral sex with his mistress because this is not what his wife does with pleasure: “... a sexual partner, a woman who would never look revolted if he asked to suck his cock, who would never clatter him with her molars in little bounces of mute revenge and then swallow what he surrendered as if it were only cruel and unusual and not a part of him” (Kennedy, 2002: 9). Every word constructing Amanda, the mistress, comes from a detour of the wife, which represents the classical example of Derrida's statement that one is a deferred other. Thus, to be Greg's mistress is only possible through the apparition of his deferred and inapparent wife in behavior, 
gestures, marks, and name. In this manner, the deferral of his wife within himself is extrapolated to the deferral of Greg's wife in his mistress. In the end, Greg experiences a mini break-down as a result of his apocalyptic visions, insomnia and guilt about his extramarital affair as he comes to realize the responsibility his "I" took in the process of differance. The character's feverish longing for the Apocalypse "by midnight tomorrow" (Kennedy, 2002: 3) could be interpreted either as his desire to confess the adultery, or as his intention to never come back home. In any case, this is the desire to stop deferring his wife within himself and try to go back to the moment and place of "now", where the character's differance set off with the "m-mark".

In White House at Night the individual issue of adultery overlaps the historical context of crimes against humanity. The main character Danny comes to Switzerland together with his wife Niamh to have some rest after they have been identifying the victims of mass atrocities and genocide in an unnamed country of Eastern Europe. The story begins with a very Derridian question of an "I" that trembles in secret: "Danny wondered where he was: where he was. Really - which was the place in his body where he felt himself to be” (Kennedy, 2002: 139). Although Kennedy puts "he" in italics, the sense of place, space, spacing becomes more important in the context of the secrecy of an "I”: Danny's questionarises from the word "where”. The place that haunts Danny - via smell, touch, and things - is a "pit", mass burial site that contains the bodies of the victims murdered by totalitarian regime: "They hadn't quite shaken the pit, though. It stayed with them: with him, Dan supposed that would be more accurate. He still had the peat smell on his hands and that other, deeper scent, or the memory of it, would rise in him when he relaxed: butyric acid, methane, sometimes a faint tang like metal and what he could only think of as the taste of unreality, of situation it would never be possible to accept, even when you were in it: perhaps most especially then” (Kennedy, 2002: 140). The place of mass murder is the scene of apparition of the inapparent, which Danny calls "retrieving the irretrievable" (Kennedy, 2002: 141). His attempts to identify the bodies do not restore historical justice Danny was longing for. Victims' bodies signify the triumph, the strength, and the victory of their tormentors. Victims are the temporalizing differance of their murderers: “There were times when they'd watched him digging, he knew - the murderers. They'd look on with this odd expression, almost coquettish, almost proud... Those intended for destruction had been destroyed - what more could one want to know? What more could there be?” (Kennedy, 2002: 141). The place where differance of the victim and the tormentor is preserved as a unity identifies Danny. He realizes there is no secret in history as well as no secret in the "I": the hauntological movement of differance that allows both to murder (to impose a mark 
upon one's body) and to die (to receive a mark in one's body) is the ultimate singular justice where one murders oneself through the Other. The apparition of the inapparent victims is always a question of repetition; they always arrive for the first time by coming back as all specters do. The specters represent the secrecy of an "I" that is there for no one, as Derrida says, and that is nothing to know about, as Kennedy claims. Danny is and is not a victim of totalitarian regime at the same time since he is defined by the mass burial sites and their victims as he is questioning his "I" through the "where" in the first sentence of the story. These apparitions of space in Danny are also extrapolated to his personal stories of adultery: whenever he works at the pits without his wife, he always finds women to have sex with as he imagines the sexual act to be the act of murder. However, when Danny realizes his wife cheats on him with their common friend, he becomes quite frustrated. Thus, all the characters in the story become both victims and tormentors of each other. They all are deferred forms of torture that are "there for no one" (Derrida, 2008).

Deferring a significant other (wife/husband/partner) is the major motif in such short stories as Awaiting An Adverse Reaction, Not Anything To Do With Love, A Little Like Light, Touch Positive, and How To Find Your Way In The Woods.

In A Bad Son a teenage boy Ronald while spending time at his friend's farm is trying to defer himself as the Ronald who could feel, worry, hurt and become "someone else now - better than he was”, become "madasfuck Ronnie” (Kennedy, 2002: 65-68). Crazy new tough Ronnie wouldn't feel anything, and this new personality sticks quite well to Ronald at daytime: “...this wasn’t pretending and wasn’t wishing - because neither of those worked -...he must be someone new now - better than he was maybe changed just this minute, maybe by miracle” (Kennedy, 2002: 65). However, as the night comes and he stays for a sleep over in his friend's house, when "he was by himself without a sound [...] there was nothing left to stop him knowing" (Kennedy, 2002: 80). What Ronnie knows that there is no crazy tough Ronnie of the day, and the only Ronnie there is, is the one who is the deferred presence of his mother systematically and brutally beaten by his father. The desire to create other Ronnie is linked to the desire to stop feeling pain in his mother and through his mother; it's the desire to stop being the deferred mother: "and he wasn't Mad Ronnie any more, was only himself and couldn’t fight it” (Kennedy, 2002: 83). Ronald wants to stop thinking of his father, to get rid of him, and to never identify through him. Moreover, he dreams of the moment when he could hit his father back, when he could really become a "bad son". Nevertheless, in this movement of inner differance 
Ronald already is the person he's only willing to be in the future: a bad son for his father through being a deferred presence of his mother.

This type of inner deferring is represented in some other short stories: in Elsewherea woman tries to come to terms with her self through self-hatred, and in Immaculate Man a gay character who falls in love with his heterosexual-for-others and homosexual-for-him boss.

This inner type of deferring one’s self where an “I” trembles in secret doesn’t differ much from deferring the other. These types of differance run on the same hauntological patterns of apparition of the inapparent: through marking/engraving marks/putting "grapho" over the texture of bodies, memories, paper. Hauntological meaning of Latin word "differre" (in its spatial and temporal sense) stands as a semantic dominance in A.L. Kennedy's collection Indelible Acts and fictionally represents the violent nature of an "I" reaching out for its most secret self in an infinitely disjoint time of "now": "As soon as there is the one, there is murder, wounding, traumatism. The one guards against the other, it protects itself from the other. But in the movement of this jealous violence it compromises in itself its selfotherness or self difference. The difference from within one's self, which makes it one. The one as the other.At one and the same time, but in the same time that is out of joint. The one forgets to remember itself to its self. It keeps and erases the archive of this injustice that it is, of this violence that it does. The one makes itself violence, it violates and does violence to itself. It becomes what it is, the very violence that it does to itself. The determination of the self as one is violence " (Derrida, 1996).

\section{REFERENCES}

Derrida, J. (1996). Archive Fever. Chicago: The University of Chicago Press.

Derrida, J. (2004). 'Différance', Literary Theory: An Anthology. Malden : Blackwell Publishing.

Derrida, J. (2008). The Gift of Death. Chicago and London: The University of Chicago Press.

Derrida, J. (2006). Specters of Marx. New York: Routledge Classics.

Kennedy, A. L. (2002). Indelible Acts. London: Jonathan Cape. 
Royle, N. (2003). Jacques Derrida. London and New York: Routledge.

Smith, A. (2002). 'Possibly Impossible'. The Guardian, https://www.theguardian.com/ books/2002/oct/12/fiction.alismith

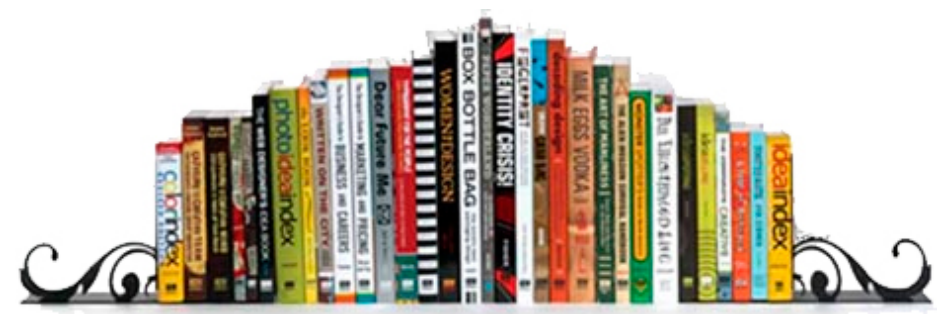

